\title{
Relation between Potassium Balance and Aldosterone Secretion in Normal Subjects and in Patients with Hypertensive or Renal Tubular Disease *
}

\author{
Paul J. Cannon, Richard P. Ames, and John H. Laragh $\dagger$ \\ (From the Department of Medicine, College of Physicians and Surgeons, Columbia University, \\ and the Presbyterian Hospital, New York, N. Y.)
}

The mechanisms that control the adrenal secretion of aldosterone are not completely understood. Recent evidence suggests that the release of renin from the kidneys with subsequent stimulation of aldosterone secretion by angiotensin may play a major role in the regulation of sodium balance (1-7). Furthermore, the secretion of renin has been linked to changes in sodium balance (8-10).

Through its action on the kidneys aldosterone not only influences sodium excretion but also plays an important role in the regulation of potassium balance. Since potassium balance may change independently of sodium balance, the possibility must be recognized that changes in potassium balance could also play an important role in the regulation of aldosterone secretion. Previous studies have shown that potassium administration can stimulate aldosterone secretion in the dog $(11,12)$, and balance studies in man have indicated that changes in potassium intake exert slight effects on urinary excretion of aldosterone (13-17).

For this reason and because situations exist in which hypersecretion of aldosterone occurs without clinical evidence to suggest marked angiotensinemia the present study was undertaken to define in man, under conditions in which sodium intake was rigidly controlled, the character of the aldosterone response to changes in potassium balance.

* Submitted for publication October 25, 1965 ; accepted February 24, 1966.

This work was supported by grants HE-15031, HE01275, and HE-05741 from the National Institutes of Health.

$\dagger$ Address requests for reprints to Dr. John H. Laragh, Dept. of Medicine, College of Physicians and Surgeons, Columbia University, 630 West 168th St., New York, N. Y. 10032 .
The data demonstrate that potassium salt administration stimulates aldosterone secretion in normal man. Depending upon the state of sodium balance or the disease state present, the magnitude of the stimulus to aldosterone secretion produced by potassium administration can equal or exceed that produced by an infusion of angiotensin II.

\section{Methods}

The 23 normal volunteers and the 23 patients who participated in this study were admitted to the metabolism ward where they were given a constant daily diet of known electrolyte content. The subjects received the control diet for at least 4 to 6 days before a study was started.

Patients with elevated blood pressures but no evidence of cardiac or retinal complications were classified as primary (benign essential) hypertension (6). Patients with high blood pressures and evidence of renal or retinal complications were classified as advanced hypertension (4). Criteria for retinal complications were the presence of hemorrhages or exudates. Renal complications were defined as the presence of proteinuria $(2+)$ or a blood urea nitrogen greater than $30 \mathrm{mg}$ per $100 \mathrm{ml}$. Patients with unequivocal papilledema were classified as malignant hypertension. Hypertensive patients with renal arterial stenosis were verified by aortography or at operation (7). Each of the three hypertensive patients with primary aldosteronism had oversecretion of aldosterone that was corrected by removal of an adrenal tumor. No patient with a blood urea nitrogen greater than $45 \mathrm{mg}$ per $100 \mathrm{ml}$ was studied.

The patient with renal tubular acidosis was a 33-yearold female with a clinical syndrome (18) characterized by inability to lower urinary $\mathrm{pH}$ below 6.3 , hypokalemia, nephrocalcinosis, and a normal level of blood urea nitrogen. Balance data suggested impairment of renal sodium conservation. The other patient with nephropathy was an 11-year-old Negro boy with clinical features similar to patients with the syndrome of primary juxtaglomerular complex hyperplasia (19). He was not edematous, had normal levels of blood pressure and blood urea nitrogen, and exhibited severe renal 
wastage of potassium, impaired ability to conserve sodium, and a marked hypokalemic alkalosis.

Potassium was administered orally four times daily as the chloride salt ( $20 \%$ solution) or as an aqueous mixture of potassium citrate, bicarbonate, and gluconate. A negative $\mathrm{K}^{+}$balance was induced by the administration of a nutritionally adequate milk product diet $^{1}$ that contained $5 \mathrm{mEq}$ of sodium and 3 to $5 \mathrm{mEq}$ of potassium per day. Potassium depletion was also induced by oral administration of $0.5 \mathrm{~g}$ chlorothiazide, 50 $\mathrm{mg}$ hydrochlorothiazide, or $50 \mathrm{mg}$ ethacrynic acid, all given four times daily. In every situation involving altered potassium balance the plasma potassium concentration or the electrocardiograms, or both, were monitored frequently.

Metabolic ward techniques and the analytical methods for the measurement of plasma and urinary electrolytes and blood urea nitrogen have been reported previously $(20,21)$. Venous blood for measurement of plasma electrolytes was drawn each morning 60 to 90 minutes after an oral $\mathrm{K}^{+}$load. Serial determinations throughout the day in eight patients revealed that in most subjects peak blood levels occurred at this time. Aldosterone secretion rates were measured by an isotope dilution technique in which 7 or $1-2$ tritium-labeled aldosterone ${ }^{2}$ that had been checked for purity and stability was utilized. One to $2 \mu \mathrm{c}$ of the labeled hormone dissolved in 5 to $10 \mathrm{ml}$ of $10 \%$ ethanol was injected intravenously at the beginning of each study. The subsequent 24-hour urine was incubated at $\mathrm{pH} 1$ for 24 hours. The aldosterone liberated by this procedure was identified by paper chromatography, eluted, and then acetylated with acetic anhydride $-{ }^{14} \mathrm{C}$ to form aldosterone diacetate. After further chromato-

1 Prepared by Mead Johnson Laboratories, Evansville, Ind.

2 U. S. Public Health Service. graphic purification on a paper and on a Celite column the ${ }^{3} \mathrm{H}$ to ${ }^{14} \mathrm{C}$ ratio of the purified sample was determined, and from this the 24-hour secretion rate of aldosterone was calculated utilizing standard isotope dilution equations. The final values were corrected for isotope displacement (22). Twenty-four-hour excretion rates of the acid labile conjugate of aldosterone were also measured by the same principle and analytic procedures. For the latter determination, however, a known amount of the labeled hormone was added to the urine after hydrolysis but before extraction. By these methods normal subjects on unrestricted diets may exhibit secretion rates ranging from 75 to $300 \mu \mathrm{g}$ per day and excretion rates from 7 to $30 \mu \mathrm{g}$ per 24 hours, with the variation depending to a great extent on the sodium intake.

\section{Results}

The results of 69 metabolic balance studies (of from 5 to 30 days in duration) carried out on 46 subjects are presented in Figures 1 to 7 and Tables I to III.

\section{Potassium administration to normal subjects}

Normal sodium diet. In Table I and Figure 1 data are presented from balance studies of four normal volunteers who received potassium chloride by mouth ( 104 and $160 \mathrm{mEq}$ per day) for 4 to 6 days. Potassium supplements produced modest increases in both aldosterone secretion rates $(+103$ and $+55 \mu \mathrm{g}$ per 24 hours) and aldosterone excretion rates $(+33$ and $+5 \mu \mathrm{g}$ per 24 hours). The induced increases in plasma potas-

TABLE I

Effect of potassium administration upon the aldosterone secretion and excretion of normal subjects

\begin{tabular}{|c|c|c|c|c|c|c|c|c|c|c|}
\hline \multirow[b]{2}{*}{ Date } & \multicolumn{2}{|c|}{ Diet } & \multirow{2}{*}{$\begin{array}{l}\text { Aldos- } \\
\text { terone } \\
\text { secre- } \\
\text { tory } \\
\text { rate }\end{array}$} & \multirow{2}{*}{$\begin{array}{l}\text { Excre- } \\
\text { tion } \\
\text { rate }\end{array}$} & \multirow[b]{2}{*}{ Weight } & \multirow[b]{2}{*}{ Volume } & \multicolumn{3}{|c|}{ Urinary } & \multirow[b]{2}{*}{ Plasma $\mathrm{K}^{+}$} \\
\hline & $\mathrm{Na}^{+}$ & $\mathrm{K}^{+}$ & & & & & $\mathrm{Na}^{+}$ & $\mathrm{K}^{+}$ & $\mathrm{Cl}^{-}$ & \\
\hline & \multicolumn{2}{|c|}{$m E q / 24$ hours } & \multicolumn{2}{|c|}{$\mu g / 24$ hours } & $k g$ & $\mathrm{ml} / 24$ hours & \multicolumn{3}{|c|}{$m E q / 24$ hours } & $m E q / L$ \\
\hline \multicolumn{11}{|c|}{$\begin{array}{l}\text { Normal sodium diet }+ \text { potassium chloride } \\
\text { NJ, 34-year-old male }\end{array}$} \\
\hline $\begin{array}{l}3 / 8 \\
3 / 9 \\
3 / 10\end{array}$ & $\begin{array}{l}86 \\
86 \\
86\end{array}$ & $\begin{array}{l}103 \\
103 \\
264\end{array}$ & 289 & 34.6 & $\begin{array}{l}66.3 \\
66.2 \\
66.4\end{array}$ & $\begin{array}{l}1,670 \\
1,500 \\
1,740\end{array}$ & $\begin{array}{r}65 \\
57 \\
116\end{array}$ & $\begin{array}{r}98 \\
87 \\
223\end{array}$ & $\begin{array}{r}82 \\
76 \\
249\end{array}$ & \multirow{2}{*}{$\begin{array}{l}5.4-11 \text { a.m.; 5.1-12 noon } \\
5.1-1 \text { p.m. } \\
4.5 \\
4.6 \\
4.7-9 \text { a.m.; 5.3-12 noon } \\
4.0 \\
5.4\end{array}$} \\
\hline $\begin{array}{l}3 / 11 \\
3 / 12 \\
3 / 13 \\
3 / 14 \\
3 / 15 \\
3 / 16\end{array}$ & $\begin{array}{l}86 \\
86 \\
86 \\
86 \\
86 \\
86\end{array}$ & $\begin{array}{l}264 \\
264 \\
264 \\
264 \\
103 \\
103\end{array}$ & $\begin{array}{l}419 \\
291\end{array}$ & $\begin{array}{l}67.9 \\
34.4\end{array}$ & $\begin{array}{l}66.4 \\
66.3 \\
66.3 \\
66.4 \\
66.2 \\
66.5\end{array}$ & $\begin{array}{l}1,540 \\
1,580 \\
1,340 \\
1,600 \\
1,150 \\
1,400\end{array}$ & $\begin{array}{l}96 \\
72 \\
65 \\
71 \\
38 \\
66\end{array}$ & $\begin{array}{r}223 \\
243 \\
253 \\
238 \\
109 \\
96\end{array}$ & $\begin{array}{r}261 \\
258 \\
254 \\
240 \\
89 \\
84\end{array}$ & \\
\hline \multicolumn{11}{|c|}{$\begin{array}{l}\text { Low sodium diet }+ \text { potassium chloride } \\
\text { GR, 31-year-old male }\end{array}$} \\
\hline $\begin{array}{l}5 / 9 \\
5 / 10 \\
5 / 11 \\
5 / 12 \\
5 / 13 \\
5 / 14 \\
5 / 15\end{array}$ & $\begin{array}{l}17 \\
17 \\
17 \\
17 \\
17 \\
17 \\
17\end{array}$ & $\begin{array}{l}115 \\
115 \\
115 \\
275 \\
275 \\
275 \\
275\end{array}$ & $\begin{array}{l}336 \\
317\end{array}$ & 73 & $\begin{array}{l}73.2 \\
73.2 \\
73.4 \\
72.7 \\
73.3 \\
72.9 \\
72.7\end{array}$ & $\begin{array}{l}2,030 \\
2,000 \\
1,700 \\
2,240 \\
1,740 \\
2,380 \\
2,260\end{array}$ & $\begin{array}{l}27 \\
30 \\
14 \\
28 \\
24 \\
37 \\
37\end{array}$ & $\begin{array}{r}76 \\
85 \\
90 \\
239 \\
104 \\
342 \\
285\end{array}$ & $\begin{array}{r}18 \\
27 \\
85 \\
135 \\
172 \\
211 \\
224\end{array}$ & 4.2 \\
\hline
\end{tabular}




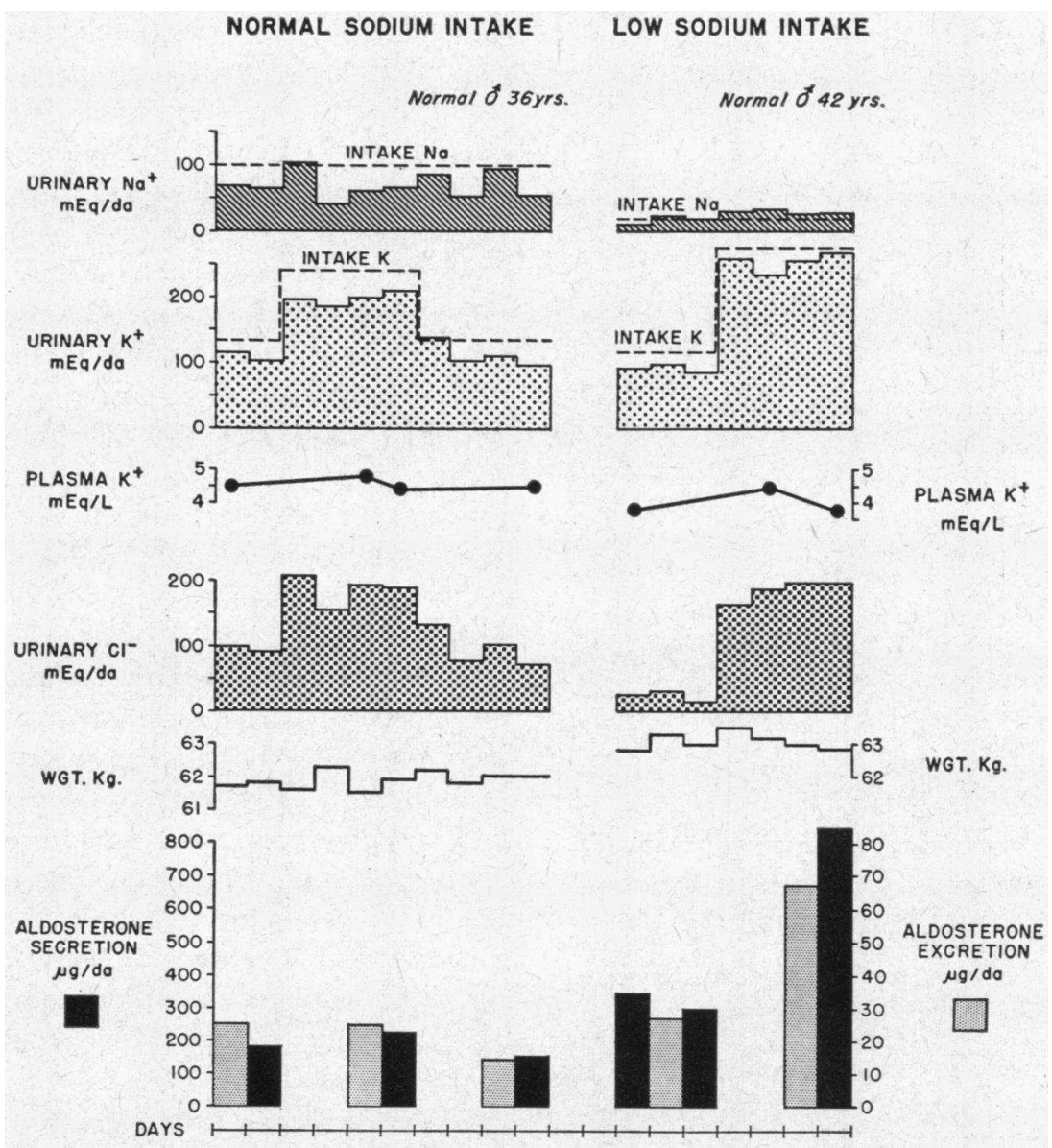

Fig. 1. Potassium administration and aldosterone secretion in NORMal SUBJECTS-MODIFYING INFLUENCE OF SODIUM BALANCE. $\mathrm{K}^{+}$administration had very little effect on the secretory and excretory rates of aldosterone when sodium intake was normal. However, in a sodium-deprived normal subject feeding of similar amounts of potassium caused a striking increase in aldosterone secretion.

sium concentration did not exceed $+0.3 \mathrm{mEq}$ per L. A marked rise in urinary $\mathrm{K}^{+}$output occurred. There were no consistent changes in urinary sodium excretion or in body weight. In 15 similar balance studies in which an average of $120 \mathrm{mEq}$ of potassium was added to a normal sodium diet for 4 to 6 days, the secretion rate of aldosterone rose by a mean of $107 \mu \mathrm{g}$ per 24 hours (Figure 2). Both the secretion and excretion rates of aldosterone returned to control values a few days after potassium supplements were stopped.

Low sodium diet. In contrast, the administration of similar amounts of potassium (mean, 150 $\mathrm{mEq}$ of $\mathrm{K}^{+}$orally per 24 hours) for 4 to 6 days produced much larger increases in the aldosterone secretion and excretion rates of normal subjects after sodium depletion. Sodium depletion was achieved by a low salt diet alone in six studies and by a low salt diet combined with administration of saliuretic diuretics (four studies). As illustrated by two representative studies presented in detail (Table I, Figure 1) potassium administration usually caused neither significant natriuresis nor loss of weight. Plasma concentrations of potassium increased, but they remained in the same range ( 3.5 to $5.5 \mathrm{mEq}$ per L) as in the studies of subjects who received a normal sodium intake.

In ten studies of salt-depleted normal subjects the mean increment in aldosterone secretion induced by potassium feeding was $841 \mu \mathrm{g}$ per 24 hours (Figure 2). During $\mathrm{K}^{+}$administration in studies of this group the mean change in plasma 


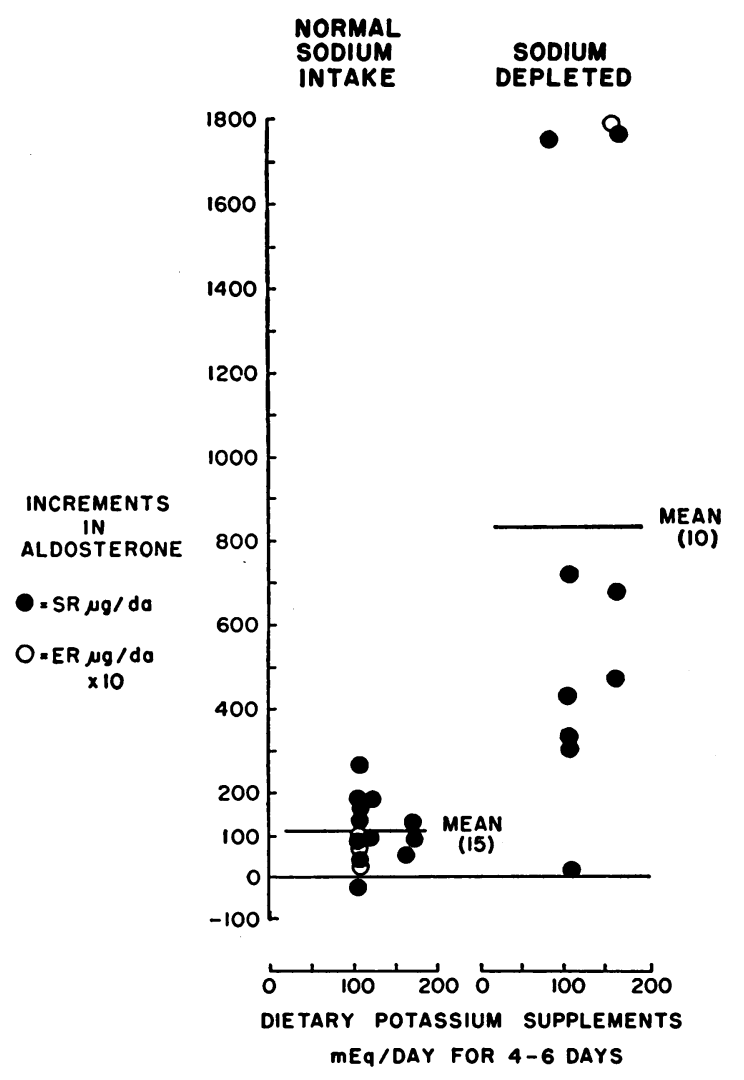

Fig. 2. INCREMENTS IN ALDOSTERONE SECRETION AND EXCRETION PRODUCED BY POTASSIUM ADMINISTRATION IN NORMAL SUBJECTS-THE MODIFYING INFLUENCE OF SODIUM DEPLETION. When the subjects were maintained on a normal sodium intake, the mean increment in aldosterone secretion was $+107 \mu \mathrm{g}$ per day. This was associated with a mean weight gain of $1.1 \mathrm{~kg}$ and a mean change in plasma $\mathrm{K}^{+}$of $-0.1 \mathrm{mEq}$ per $\mathrm{L}$. However, after sodium depletion potassium increased aldosterone secretion by a mean of $+841 \mu \mathrm{g}$ per day. This effect was associated with mean changes of $+0.5 \mathrm{~kg}$ in weight and $+0.7 \mathrm{mEq}$ in plasma potassium. $\mathrm{SR}=$ secretion rate; $\mathrm{ER}=$ excretion rate.

potassium concentration was $+0.7 \mathrm{mEq}$ per $\mathrm{L}$; mean weight change was $+0.51 \mathrm{~kg}$. The greatest increments in aldosterone secretion that were induced by potassium occurred in four subjects in whom the degree of sodium depletion had been increased by the administration of saliuretic diuretics 4 to 6 days before onset of the study.

\section{Potassium depletion in normal subjects}

Normal sodium diet. In two normal subjects (Figure 3, Table II) the administration of a sup- plemented synthetic diet containing 86 to $102 \mathrm{mEq}$ of sodium and 3 to $5 \mathrm{mEq}$ of potassium per day was followed by significant reductions in the adrenal secretion rate of aldosterone ( -52 and $-202 \mu \mathrm{g}$ per 24 hours). During this period potassium balance was negative (cumulative $\mathrm{K}^{+}$balances : -166 and $-122 \mathrm{mEq} \mathrm{K} \mathrm{K}^{+}$, and a moderate hypokalemia (plasma $\left[\mathrm{K}^{+}\right], 3.5$ and $3.7 \mathrm{mEq}$ per L) ensued. Both subjects maintained a normal sodium balance.

Low sodium diet. In two other normal subjects (Figure 3, Table II) administration of an artificial diet deficient both in sodium and potassium resulted in negative sodium and potassium balances (cumulative $\mathrm{K}^{+}$balances: -196 and $-124 \mathrm{mEq} \mathrm{K} \mathrm{K}^{+}$) and modest falls in plasma potassium concentration (plasma $\left[\mathrm{K}^{+}\right], 3.3$ and 3.2 $\mathrm{mEq}$ per $\mathrm{L}$ ). The secretion rate of aldosterone increased somewhat in the subjects $(+162$ and $+213 \mu \mathrm{g}$ per 24 hours); however, the normal rise in aldosterone secretion usually observed after sodium restriction (23) was considerably blunted. In one of the subjects (Figure 4) the administration of oral $\mathrm{K}^{+}$after 6 to 7 days induced a sharp rise in aldosterone secretion $(+310 \mu \mathrm{g}$ per 24 hours) to the expected high levels, but only a slight rise $(+0.8 \mathrm{mEq}$ per $\mathrm{L})$ in plasma $\left[\mathrm{K}^{+}\right]$.

Diuretic-induced potassium depletion. In 11 studies diuretic agents known to increase potassium excretion were administered to normal subjects for periods of from 5 to 26 days. In five studies $80 \mathrm{mEq}$ or more of dietary $\mathrm{NaCl}$ was given in the daily diet; in six studies the diet contained only 14 to $17 \mathrm{mEq} \mathrm{NaCl}$ daily. Two representative studies of one subject appear in Figure 4. Both ethacrynic acid and hydrochlorothiazide induced natriuresis, diuresis, and loss of weight; mean weight loss for the group was $2.4 \mathrm{~kg}$. Both induced significant renal $\mathrm{K}^{+}$loss (e.g., Figure 4, cumulative $\mathrm{K}^{+}$balances: -442 and $-515 \mathrm{mEq}$ $\mathrm{K}^{+}$) and hypokalemia (mean fall in 11 studies, 1.3 $\mathrm{mEq}$ per $\mathrm{L}$; range, 0.5 to $2.3 \mathrm{mEq}$ per $\mathrm{L}$ ). However, in contrast to the effects of dietary $\mathrm{Na}^{+}$and $\mathrm{K}^{+}$depletion, aldosterone secretion rates rose to very high levels after administration of these diuretics, despite much greater potassium losses and greater degrees of hypokalemia than had been produced by dietary deprivation (Figure 4). The mean increment in daily aldosterone secretion induced by the administration of chlorothiazide, hy- 

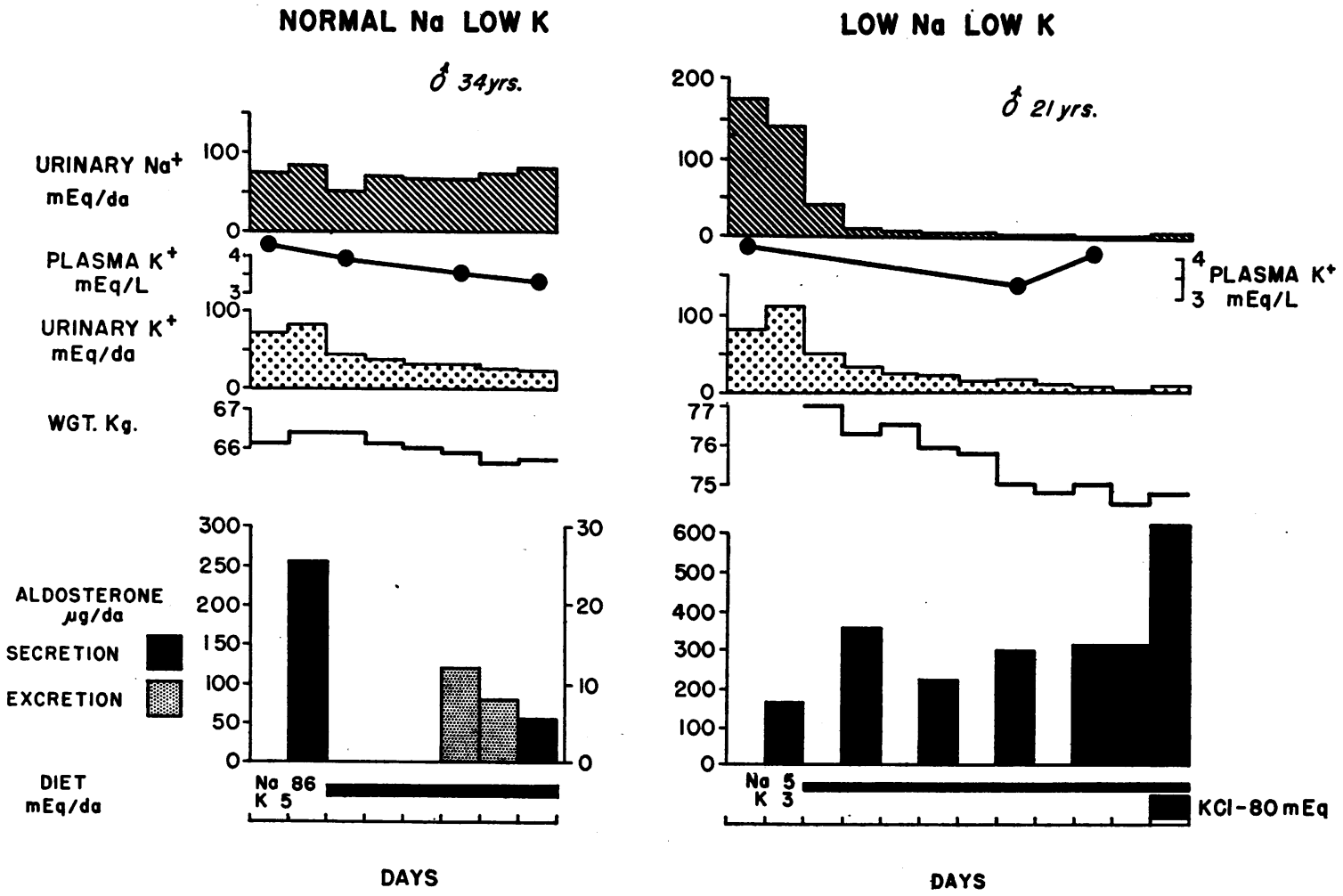

Fig. 3. Dietary potassium Deprivation in nORMal subjects. When subjects were maintained on a constant normal sodium diet, potassium deprivation caused aldosterone secretion to fall. In the subject on the right, simultaneous potassium and sodium deprivation blunted the usual use in aldosterone secretion of sodium deprivation. On the final day $\mathrm{KCl}$ repletion markedly stimulated aldosterone secretion.

drochlorothiazide, or ethacrynic acid in the 11 studies was $+777 \mu \mathrm{g}$ per 24 hours.

In three other studies in which a negative sodium balance did not result from diuretic administration, the secretion rate of aldosterone did not change or fell concomitant with diuretic-induced negative potassium balance. Oral administration of ethacrynic acid with $20 \mathrm{~g}$ of supplemental $\mathrm{NaCl}$ for 4 to 5 days in two subjects resulted in a fall in plasma $\left[\mathrm{K}^{+}\right](-1.9,-1.5 \mathrm{mEq}$ per $\mathrm{L})$, little change in weight $(+0.4 \mathrm{~kg},-0.9 \mathrm{~kg})$ with no change in aldosterone secretion in one subject and a slight fall $(-87 \mu \mathrm{Eq}$ per 24 hours) in the other. In a third subject whose aldosterone secretion rate had reached very high levels after prolonged salt depletion and administration of ethacrynic acid, the oral administration of chlorothiazide ( $2 \mathrm{~g}$ daily for 8 days) did not induce further natriuresis but caused a significant kaliuresis with a fall of serum $\left[\mathrm{K}^{+}\right]$to $2.5 \mathrm{mEq}$ per $\mathrm{L}$. This was associated with a decline in aldosterone secretion from $3,150 \mu \mathrm{g}$ per 24 hours to $1,008 \mu \mathrm{g}$ per 24 hours.

\section{Potassium administration in arterial hypertension}

Primary hypertension. Six patients with essential hypertension were studied similarly. Four received a normal sodium intake (82 to $107 \mathrm{mEq}$ dietary sodium daily). Two were sodium depleted (11 $\mathrm{mEq} \mathrm{Na}{ }^{+}$per day). Each patient received 87 to $107 \mathrm{mEq}$ of potassium salts orally for 4 to 6 days.

The aldosterone responses observed (Table III) were qualitatively similar but smaller than those observed in normal subjects (Figure 2). When maintained on a normal sodium diet either a slight rise or a fall in aldosterone secretion or excretion occurred during potassium feeding. The mean increment in aldosterone secretion observed in the four patients was $+7 \mu \mathrm{g}$ per 24 hours. In two other hypertensive subjects who had previously 
been sodium depleted aldosterone secretion rose by a mean of $410 \mu \mathrm{g}$ per 24 hours in response to potassium administration.

Hypertension secondary to renal arterial stenosis. Nine similar studies were performed on seven patients with hypertension secondary to renal arterial stenosis (Table III) ; $107 \mathrm{mEq}$ of $\mathrm{KCl}$ was administered orally for 4 to 7 days. All these subjects received a normal ( 82 to $107 \mathrm{mEq}$ per 24 hours) sodium intake.

Control aldosterone secretion rates in this group ranged from $112 \mu \mathrm{g}$ per day (HOL) to $783 \mu \mathrm{g}$ per day (CAC). The values tended to be higher in patients with higher diastolic pressures or in those who manifested hypokalemia.

The increments in aldosterone secretion produced by potassium in this group of patients ranged from +110 to $+1,165 \mu \mathrm{g}$ per 24 hours and averaged $+507 \mu \mathrm{g}$ per 24 hours. This was associated with rises in plasma $\mathrm{K}^{+}$concentration that averaged $+0.8 \mathrm{mEq}$ per $\mathrm{L}$ and with variable changes in weight (mean $-0.8 \mathrm{~kg}$ ).

Advanced and malignant hypertension. Four patients with advanced hypertension received po- tassium supplements while on a normal sodium intake (Table III). Control values for aldosterone secretion were slightly elevated in these patients (295 to $552 \mu \mathrm{g}$ per 24 hours). Potassium administration caused significant increases in aldosterone output $(+266$ to $+784 \mu \mathrm{g}$ per 24 hours). The mean increment in aldosterone of $+434 \mu \mathrm{g}$ per 24 hours was accompanied by a mean change in plasma $\left[\mathrm{K}^{+}\right]$of $+1.1 \mathrm{mEq}$ per $\mathrm{L}$ and a mean weight change of $+0.2 \mathrm{~kg}$. Subsequent sodium depletion in one patient (BUL) increased her aldosterone response to potassium (Table III).

The elevated aldosterone secretion rates of two patients with malignant hypertension increased more than twofold in response to potassium $(+1,297$ and $+1,500 \mu \mathrm{g}$ per 24 hours $)$. Both of these patients received a normal sodium intake during the study. A detailed balance of one (LU) who progressed from advanced to malignant hypertension appears in Figure 5. In this patient a negative sodium balance did not accompany the large increment in aldosterone secretion induced by potassium. A greater rise in aldosterone out-

TABLE II

Effect of dietary potassium depletion upon aldosterone secretion of normal subjects

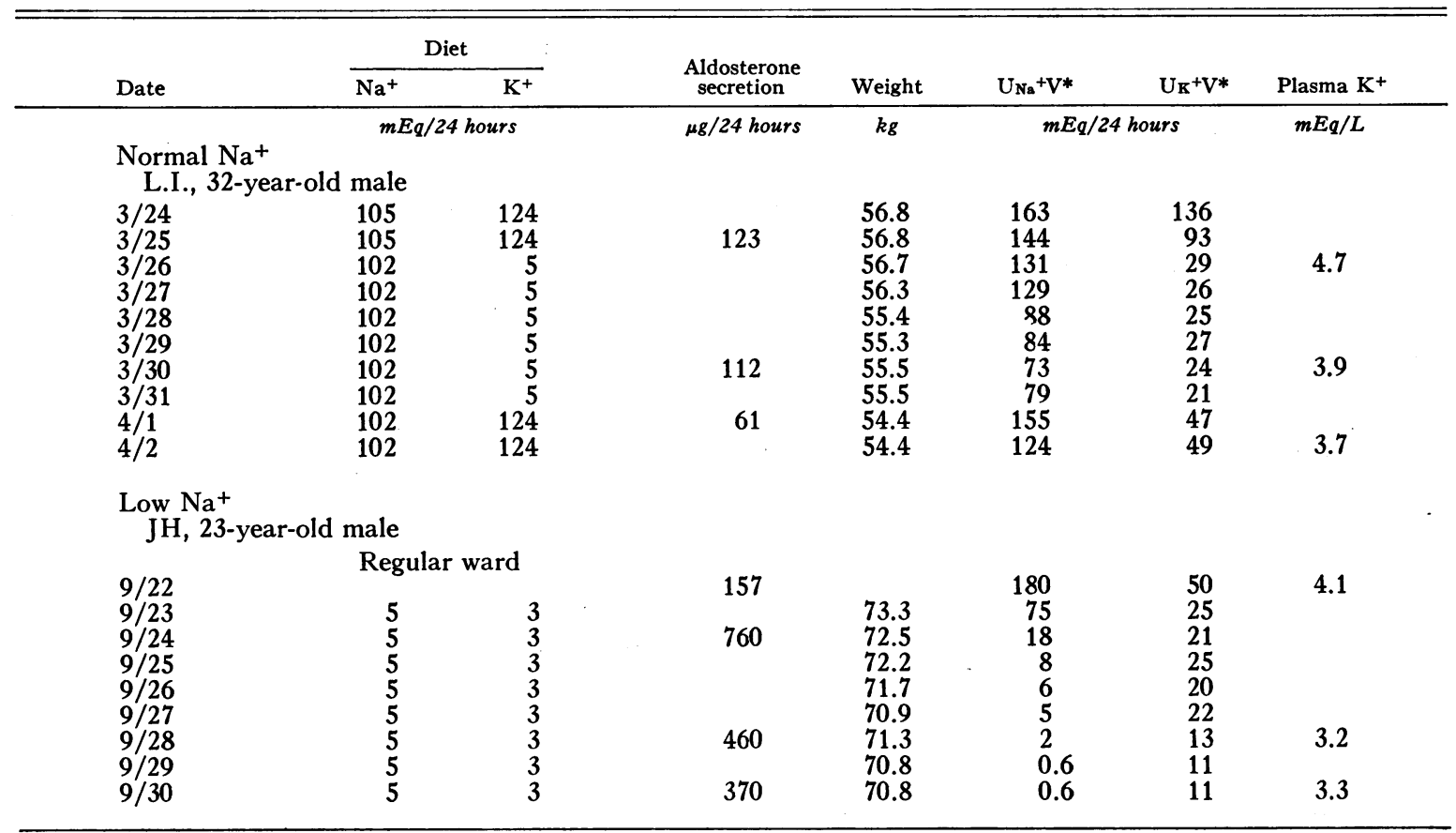

* $\mathrm{U}_{\mathrm{Na}}+\mathrm{V}=$ urinary sodium excretion, and $\mathrm{U}_{\mathrm{K}}+\mathrm{V}=$ urinary potassium excretion. 


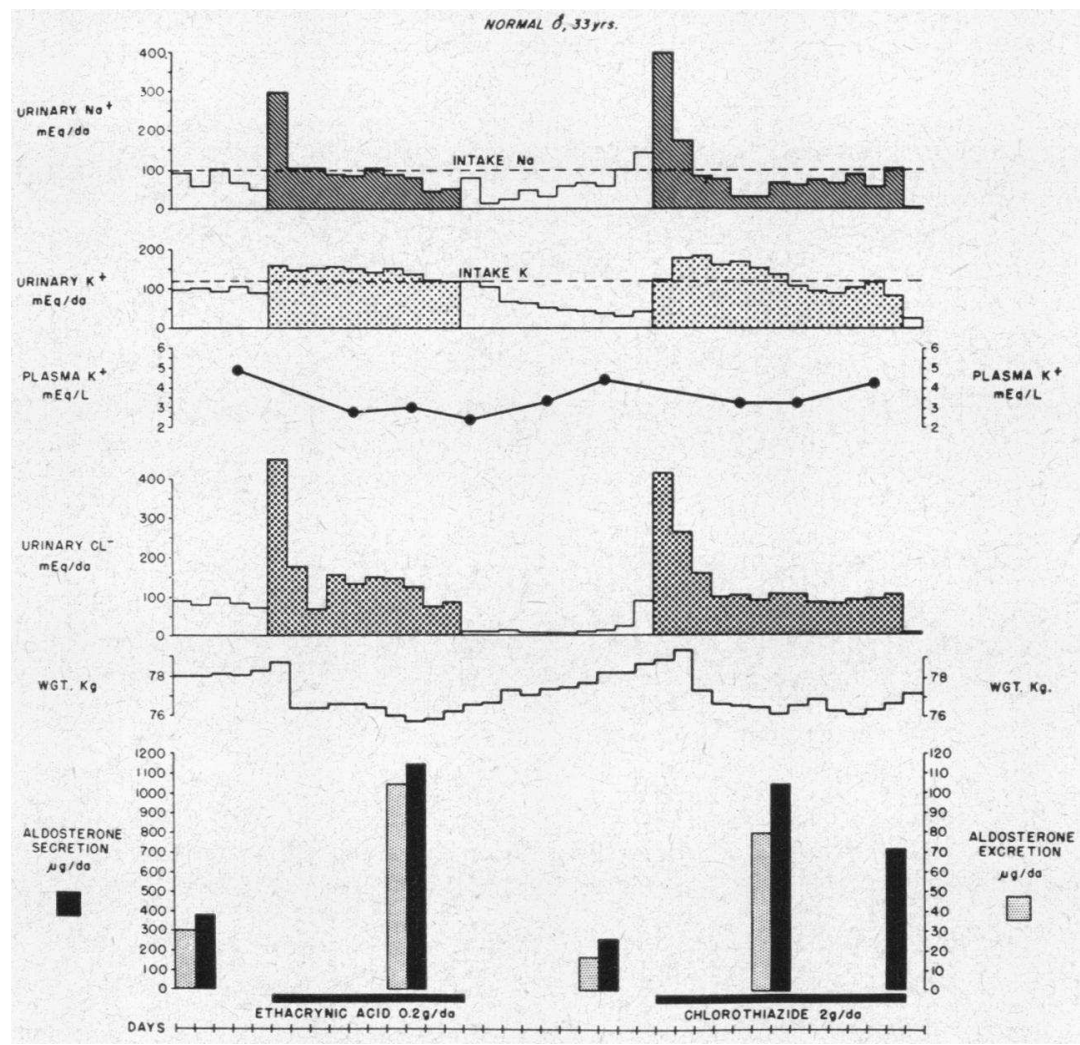

Fig. 4. EFfect of diuretics on electrolyte balance and aldosterone secreTION. Both ethacrynic acid and chlorothiazide produced weight loss and increased urinary excretion of sodium, potassium, and chloride. Despite negative potassium balances and hypokalemia in both studies aldosterone secretion and excretion rose to very high levels.

put in response to potassium administration was observed after the disease process had progressed from the advanced to the accelerated phase.

Aldosterone-secreting adenomas. In three patients in whom hypertension and hypokalemia were caused by the presence of aldosterone-secreting tumors, the administration of potassium produced very large rises in aldosterone production (mean, $+1,303 \mu \mathrm{g}$ per 24 hours). Two of these patients received normal dietary sodium; one was salt depleted. The secretion rate of one patient (BOR) rose from 1,540 to $3,802 \mu \mathrm{g}$ per 24 hours accompanied by a rise of only $1 \mathrm{mEq}$ per $\mathrm{L}$ in plasma $\mathrm{K}^{+}$concentration. A detailed balance study of another patient (Figure 5) illustrates the fall of aldosterone secretion and plasma $\left[\mathrm{K}^{+}\right]$to control values within 4 days after $\mathrm{K}^{+}$administration was discontinued.

Potassium administration to patients with renal tubular disease. The effects of oral potassium sup- plements before and after sodium depletion were determined in extended balance studies of two normotensive patients with renal tubular disease.

In both of these patients when potassium supplements were added to a regular sodium diet ( 75 to $105 \mathrm{mEq}$ per 24 hours), very large increases in aldosterone secretion rates above their control values were observed $(+336$ and $+2,581$ $\mu \mathrm{g}$ per 24 hours) (Figure 6 ). Although serum $\mathrm{K}^{+}$concentration rose, the absolute values never exceeded the normal range.

Even greater rises in aldosterone secretion occurred in response to potassium after sodium depletion. In the patient with renal tubular acidosis aldosterone output at first increased to $977 \mu \mathrm{g}$ per 24 hours with sodium restriction despite concomitant hypokalemia; it then fell to $433 \mu \mathrm{g}$ per 24 hours as renal $\mathrm{K}^{+}$wastage continued. At this point the addition of potassium supplements again caused a sharp increase in aldosterone to $2,618 \mu \mathrm{g}$ 
TABLE III-Effect of potassium administration upon the

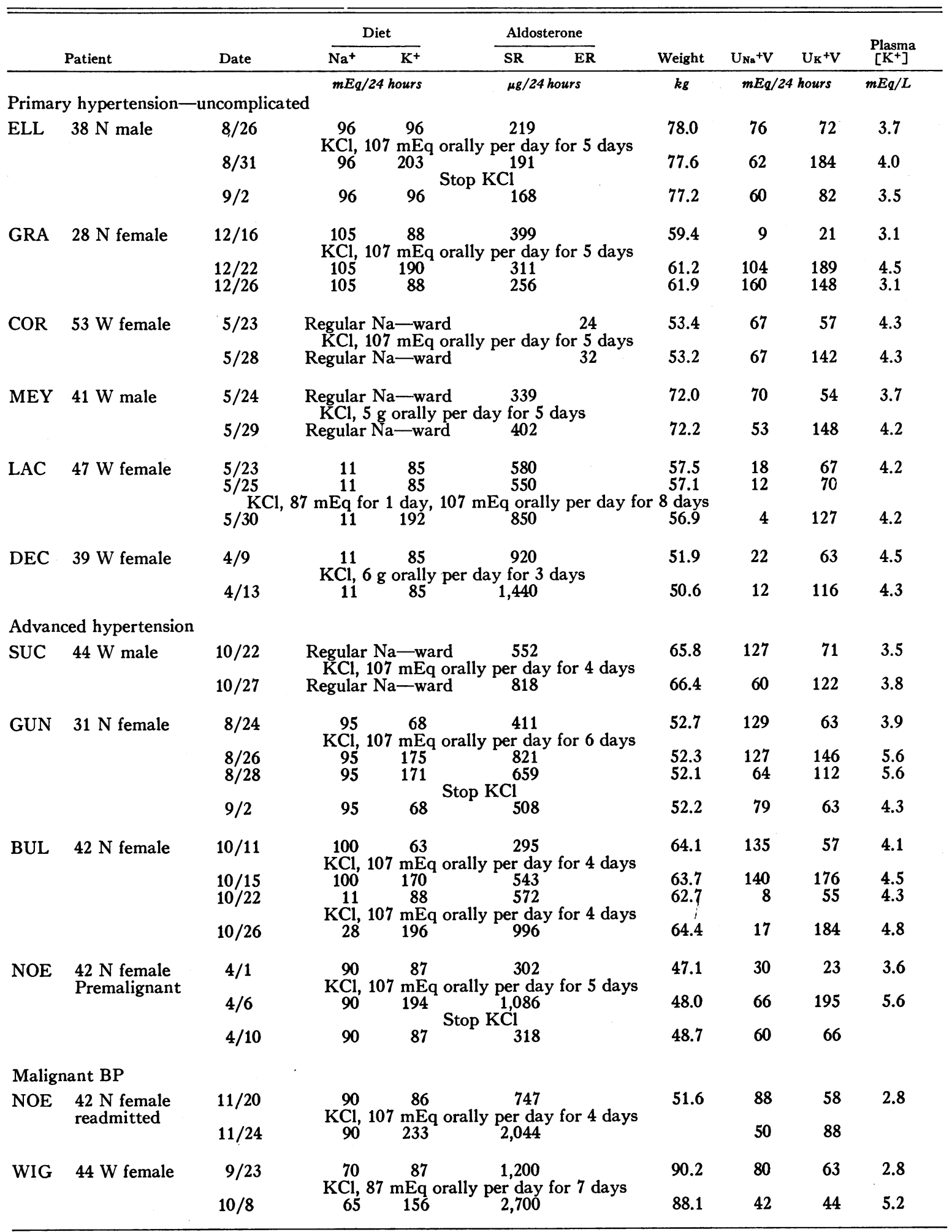

* Abbreviations: $\mathrm{SR}=$ secretion rate; $\mathrm{ER}=$ excretion rate $; \mathrm{BP}=$ blood pressure. 
aldosterone secretion and excretion of patients with hypertension*

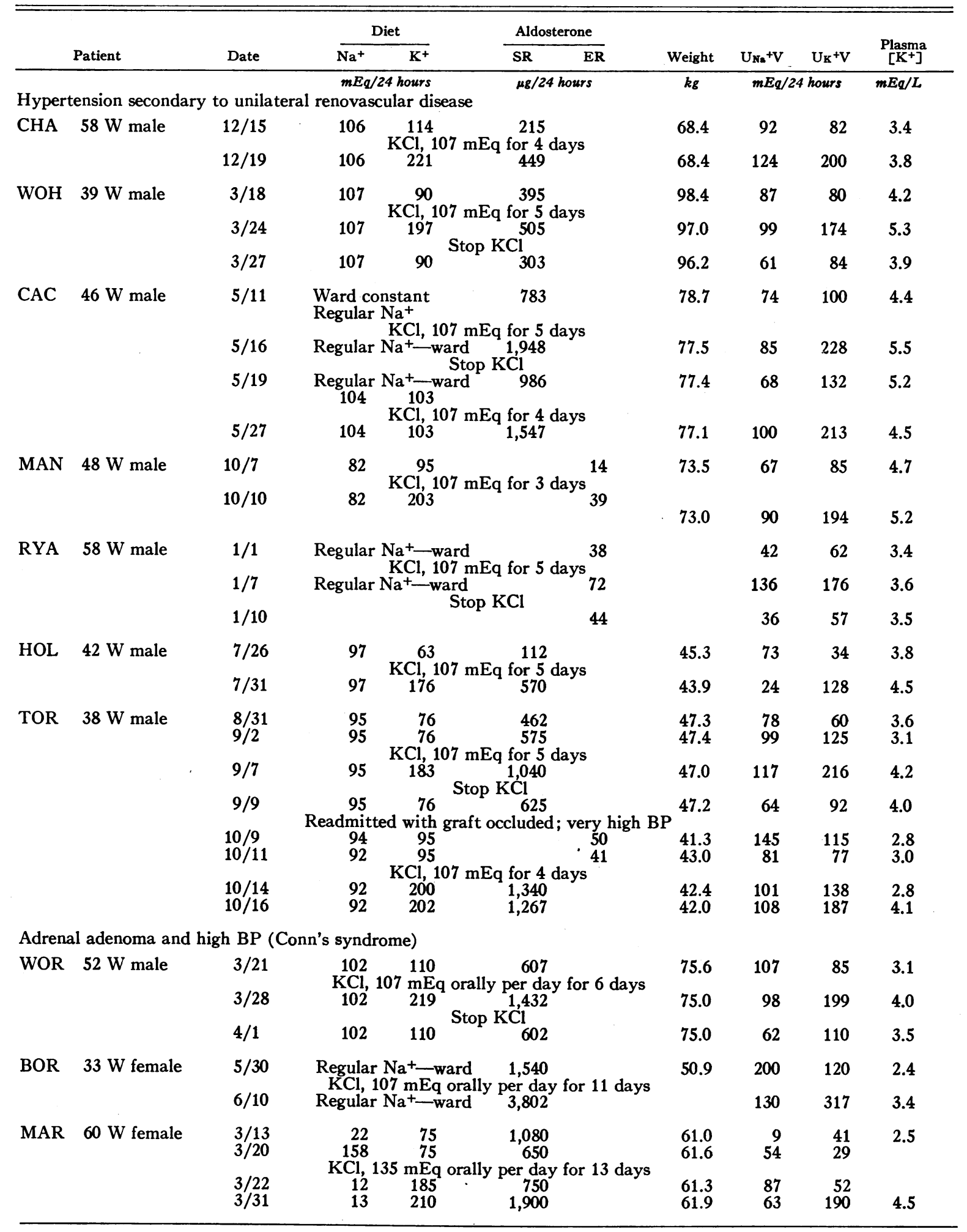




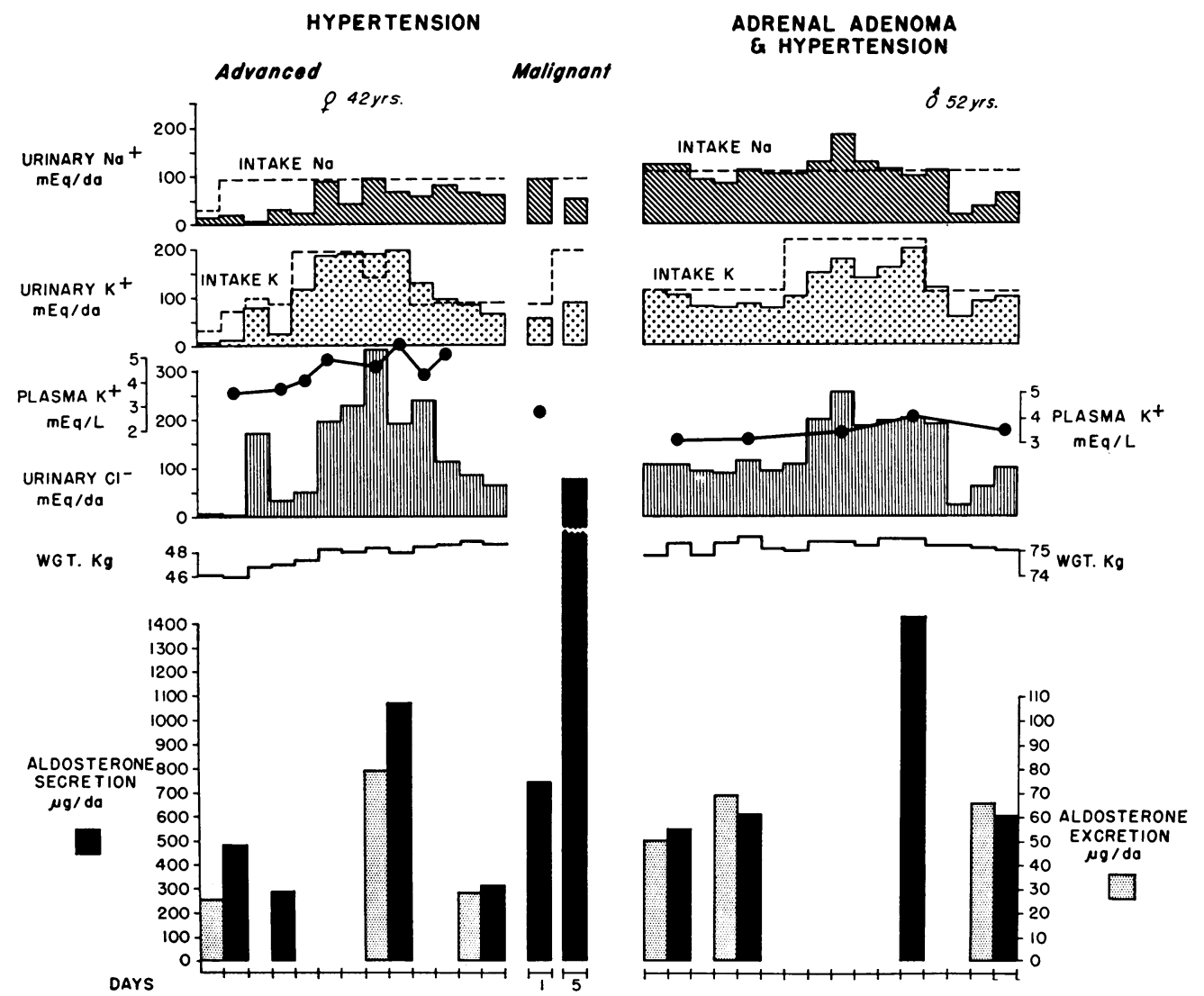

Fig. 5. Potassicm administration in Severe hypertensive disease and in primary aldosteroNISM. In contrast to normal subjects, these patients when maintained on a normal sodium intake exhibited striking increases in aldosterone secretion in response to potassium administration. The phenomenon occurred without significant changes in sodium balance. Plasma potassium levels were increased but did not exceed the normal range.

per 24 hours. In the other patient with nephropathy sodium deprivation combined with potassium administration caused an enormous rise in the aldosterone secretion rate to values over 6,500 $\mu \mathrm{g}$ per 24 hours (Figure 6).

\section{Discussion}

The data demonstrate that potassium administration stimulates, and potassium depletion retards, aldosterone secretion in man. The findings are in harmony with earlier work in the $\log (11$, $16,24,25)$ and with the reports that potassium increases the excretion of a urinary metabolite of aldosterone in man (13-17).

The present study also points up three factors that can operate to amplify adrenal responsiveness to potassium administration. These are 1 ) the state of sodium balance, 2) the presence of an illdefined disturbance of renal function (that may have activated the renin-angiotensin system) as observed in the patients with renal arterial stenosis, advanced hypertensive disease, and renal tubular disorders, and 3) the presence of aldosterone-secreting adrenal tumors.

Potassium administration to normal subjects produced only modest increments in aldosterone secretion (mean, $+107 \mu \mathrm{g}$ per day); the administration of similar amounts after sodium depletion caused marked increments in aldosterone secretion (mean, $+841 \mu \mathrm{g}$ per day). Qualitatively similar but smaller response patterns were observed in patients with essential hypertension. This modifying influence of the state of sodium balance on adrenal cortical responsiveness to potassium is opposite to that observed with infu- 
sions of angiotensin II. Sodium depletion blunts both the pressor response and the adrenal secretory response to infused angiotensin $(26,27)$ possibly because higher circulating levels of endogenous renin and angiotensin rencler their target organs hyporesponsive to exogenous polypepticle.

In a group of 13 patients with renal arterial stenosis and advanced or malignant hypertension, in two patients with renal tubular clisorders characterized by renal sodium wastage, and in three patients with primary hyperaldosteronism, the administration of similar amounts of potassium produced much greater increases in aldosterone secretion, even though these patients were receiving a normal sodium intake. In these various disorders the mean increments ranged from a low of +434 $\mu \mathrm{g}$ per day to a high of $+1,459 \mu \mathrm{g}$ per day.

The means by which changes in potassium balance affect aldosterone secretion are still not entirely clear. It seems unlikely that potassium exerts its effect by modifying sodium and water balance because in the bulk of our studies neither the stimulating effect of potassium administration nor the retarding influence of potassium deprivation was associated with any consistent change in sodium balance or in weight (Figures 1 to 3 , Tables I and II). It is true that urinary sodium excretion did rise slightly in a few subjects during potassium administration |Figures 1 (left) and 5 (right)]; however, other subjects in whom the

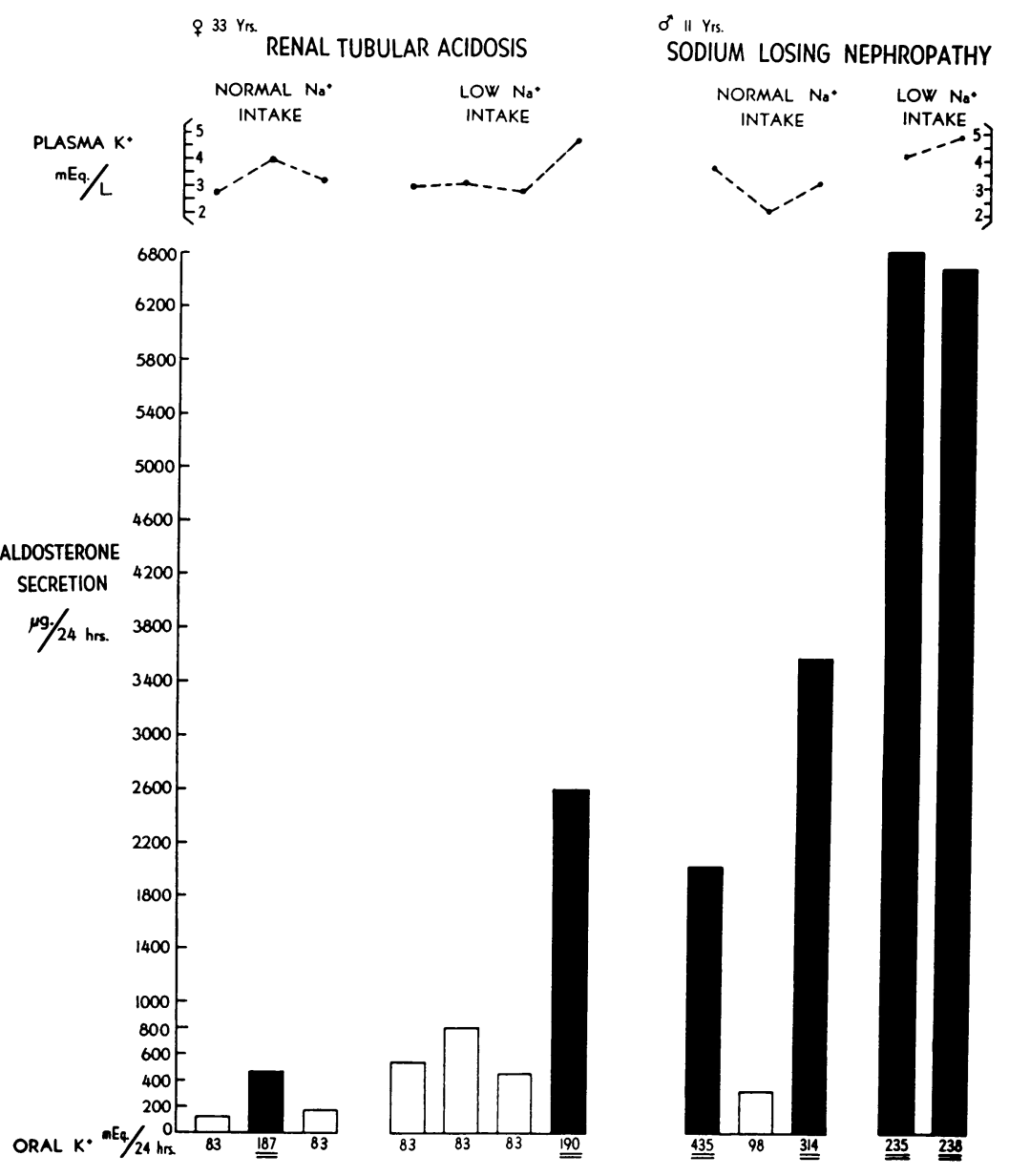

Fici. 6. EFFect of potassich adilnistration lPoN aldosterone secretion OF TWO PATIENTS WITH RENAL TLBCLAR DISEASE. Large changes in aldosterone secretion rate occurred in response to altered $\mathrm{K}^{+}$balance when the patients received a normal sodium diet. A low sodium intake plus potassium induced extreme oversecretion of the hormone. In both, serum potassium concentration increased but did not exceed normal levels. 


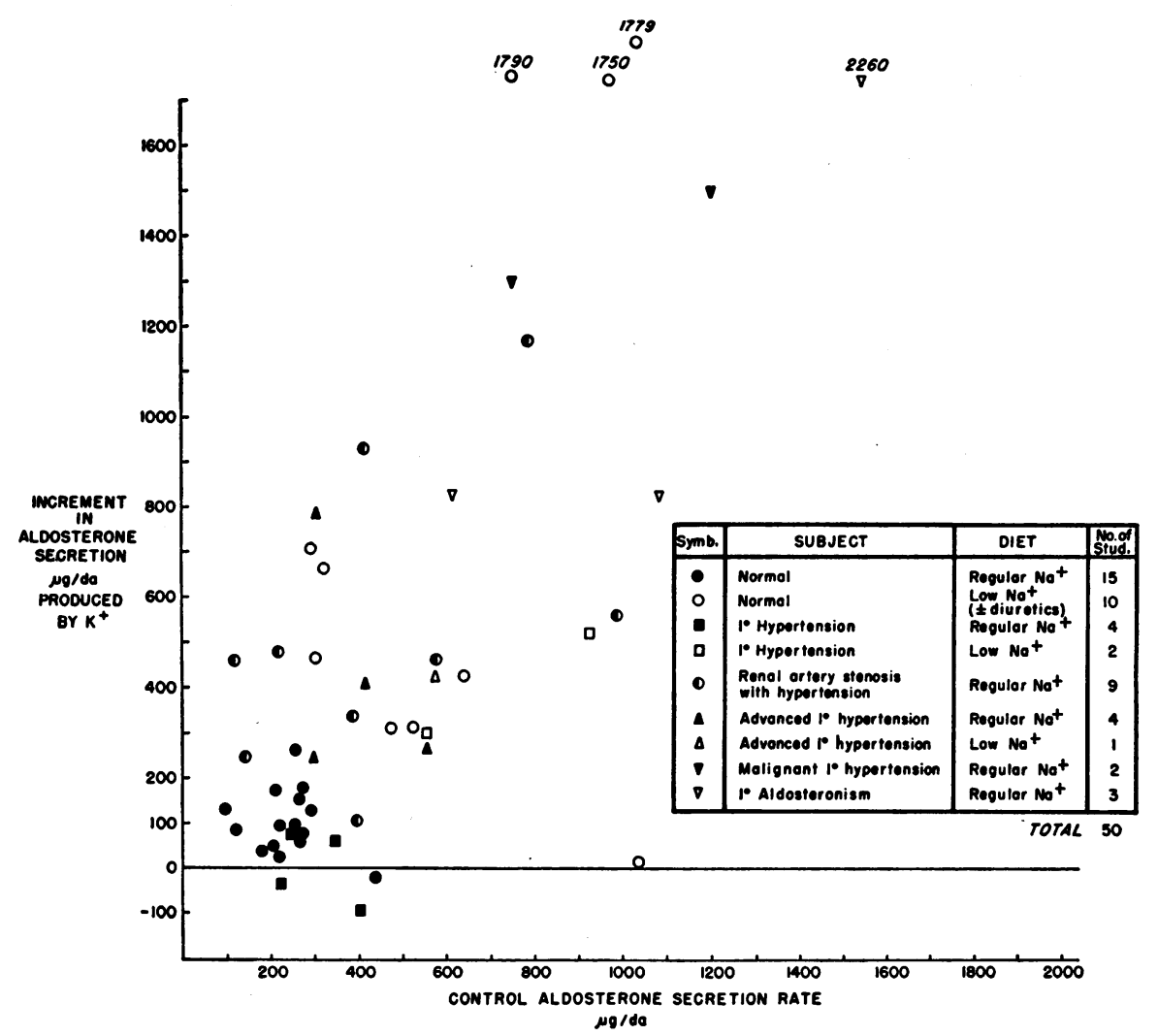

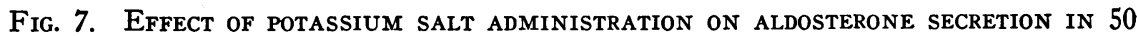
BALANCE STUDIES OF NORMAL SUBJECTS AND OF PATIENTS WITH HYPERTENSIVE DISEASES. The magnitude of the increments in aldosterone secretion induced by oral administration of 87 to $150 \mathrm{mEq}$ per day of potassium appear directly related to the control rate of aldosterone secretion.

rise in aldosterone secretion induced by potassium was the same or much larger did not exhibit such a negative sodium balance [Figures 1 (right) and 5 (left)].

Potassium administration might operate indirectly to stimulate aldosterone secretion by activating the renin-angiotensin system or by enhancing the adrenotrophic action of available circulating angiotensin. Against the former possibility are preliminary observations (28) in six subjects of the present study which indicate that potassiuminduced rises in aldosterone were not consistently accompanied by elevations of plasma renin activity. The latter idea is supported by the bulk of the present observations which indicate that the adrenal response to potassium is greatly enhanced in situations where plasma renin and angiotensin are likely to be increased (i.e., sodium depletion, renal disease, and advanced hypertensive disease)
(8-10). Against it, however, is the increased adrenal responsiveness to potassium observed in all three patients with primary aldosteronism, a situation where plasma renin activity is presumably very low (29).

Perfusion studies in dogs (12) and sheep (30) have shown that rather large changes in arterial plasma potassium levels can directly affect adrenal cortical activity. However, it may not be proper to explain the changes in aldosterone secretion observed in the present study solely in terms of alterations in plasma $\mathrm{K}^{+}$concentration. In a majority of situations (Tables I and III, Figures 1, 5 , and 6 ) potassium administration caused large increases in aldosterone secretion, whereas plasma potassium levels remained within the normal range. Also, the induced increments in potassium concentration associated with the large increases in aldosterone secretion (salt-depleted normals, ad- 
vanced hypertension, renal tubular disease) were no greater than the increments observed in the normal subjects who exhibited a minimal hormonal response to potassium salts. Lastly, the marked hypokalemia of diuretic therapy exerted less retarding influence on aldosterone secretion than the milder hypokalemia of dietary depletion. Therefore, it seems possible that the tissue uptake of potassium somewhere in the body (perhaps the adrenal glomerulosa cells), rather than the absolute level of plasma potassium, is the more critical determinant of the aldosterone response to alterations in potassium balance.

A relationship derived from the present data may improve our understanding of how potassium ions affect the adrenal cortex. The magnitude of the response of the adrenal glomerulosa to potassium observed in 50 studies of normal and hypertensive subjects was found to be directly related to the prior rate of production of aldosterone (Figure 7 ), that is, larger increments in aldosterone secretion were induced by potassium when the adrenal gland was already hyperactive. This relationship held whether adrenal overactivity resulted from an autonomous adenoma or from presumed extra-adrenal stimulation via renin (sodium depletion, diuretics, hypertensive-renal disease).

Thus, all of our results might best be explained by postulating that 1 ) adrenal cellular accumulation of potassium in response to a positive $\mathrm{K}^{+}$balance directly increases aldosterone secretion, and 2) the effect of a given amount of potassium upon adrenal production of aldosterone is directly related to the pre-existing level of adrenal stimulation by other factors. The other known factors that might operate to condition the effect of potassium on the adrenal are the level of circulating renin and angiotensin as affected by changes in sodium balance or as altered by renal dysfunction in the patients with hypertension or renal diseases, conceivably ACTH release in acute stress situations, and primary or autonomous adrenal hyperactivity as encountered in patients with adrenal tumors.

These findings complicate current concepts of the control of aldosterone and electrolyte homeostasis. They imply that there may be a double cycle feedback system whereby primary control of aldosterone secretion by the renin-angiotensin system responsive to changes in sodium balance or renal blood flow or both is supplemented and complemented by another mechanism in which a direct stimulatory effect of potassium upon the adrenal gland is conditioned by the existing level of adrenal secretory activity. Such a dual mechanism would provide a finely adjustable homeostatic defense of plasma $\mathrm{K}^{+}$concentration in the event of renal failure or in the face of any large or sudden change in potassium balance.

\section{Summary}

Dietary potassium supplements (107 to 160 $\mathrm{mEq}$ daily for 4 to 6 days) stimulated aldosterone secretion in 23 of 25 studies of normal subjects and in 24 of 26 studies of patients with hypertensive or renal tubular disease. Dietary or diuretic-induced potassium depletion reduced aldosterone secretion if simultaneous sodium depletion was avoided but did not prevent an aldosterone rise in response to renal sodium loss. The influence of potassium depletion on aldosterone secretion could not be exclusively related to plasma potassium levels because the more severe hypokalemia of diuretic therapy was accompanied by an increased, and the milder hypokalemia of dietary depletion by a reduced, aldosterone secretion.

The effect of potassium balance on aldosterone secretion could not be explained adequately by induced changes in sodium balance and activation of the renin-angiotensin system or even by observed alterations in plasma potassium levels. It may therefore result from a more subtle consequence of altered potassium balance, perhaps involving direct adrenal cellular uptake of potassium.

The aldosterone secretory response to potassium administration was enhanced by four- to tenfold or more 1) after sodium depletion in normal subjects or patients with essential hypertension, 2) in patients receiving normal sodium diets who had renal arterial stenosis, advanced or malignant hypertension, or renal tubular disease characterized by sodium wasting, and 3) in patients with primary aldosteronism. In these circumstances, the magnitude of the aldosterone response to potassium was equal to or greater than that described for angiotensin. In normal subjects and in hypertensive patients with primary or secondary aldosteronism, the aldosterone response to potassium was directly related to the pre-existing rate of aldosterone secretion, regardless of whether the 
latter resulted from an autonomous tumor or from extra-adrenal stimulation, presumably via renin.

This conditioning of the stimulatory influence of potassium upon aldosterone by the prior level of adrenal activity suggests that the regulation of aldosterone is normally controlled by a complementary interrelationship between direct adenotrophic effects of potassium and activity of the renin-angiotensin system.

\section{References}

1. Laragh, J. H. The role of aldosterone in man. Evidence for regulation of electrolyte balance and arterial pressure by a renal-adrenal system which may be involved in malignant hypertension. J. Amer. med. Ass. 1960, 174, 293.

2. Laragh, J. H., M. Angers, W. G. Kelly, and S. Lieberman. Hypotensive agents and pressor substances. The effect of epinephrine, norepinephrine, angiotensin II, and others on the secretory rate of aldosterone in man. J. Amer. med. Ass. 1960, 174, 234.

3. Laragh, J. H., P. J. Cannon, and R. P. Ames. Interaction between aldosterone secretion, sodium and potassium balance, and angiotensin activity in man: studies in hypertension and cirrhosis. Canad. med. Ass. J. 1964, 90, 248.

4. Biron, P., E. Koiw, W. Nowaczynski, J. Brouillet, and J. Genest. The effects of intravenous infusions of valine-5 angiotensin II and other pressor agents on urinary electrolytes and corticosteroids, including aldosterone. J. clin. Invest. 1961, 40, 338.

5. Davis, J. O., P. M. Hartroft, E. O. Titus, C. C. J. Carpenter, C. R. Ayers, and H. E. Spiegel. The role of the renin-angiotensin system in the control of aldosterone secretion. J. clin. Invest. 1962, 41, 378.

6. Mulrow, P. J., W. F. Ganong, G. Cera, and A. Kuljian. The nature of aldosterone-stimulating factor in dog kidneys. J. clin. Invest. 1962, 41, 505.

7. Blair-West, J. R., J. P. Coghlan, D. A. Denton, J. R. Goding, J. A. Munro, R. E. Peterson, and M. Wintour. Humoral stimulation of adrenal cortical secretion. J. clin. Invest. 1962, 41, 1606.

8. Brown, J. J., D. L. Davies, A. F. Lever, and J. I. S. Robertson. Influence of sodium loading and sodium depletion on plasma renin in man. Lancet 1963, 2, 278.

9. Brown, J. J., D. L. Davies, A. F. Lever, and J. I. S. Robertson. Variations in plasma renin concentration in several physiological and pathological states. Canad. med. Ass. J. 1964, 90, 201.

10. Veyrat, R., J. de Champlain, R. Boucher, and J. Genest. Measurement of human arterial renin activity in some physiological and pathological states. Canad. med. Ass. J. 1964, 90, 215.
11. Laragh, J. H., and H. C. Stoerk. On the mechanism of secretion of the sodium-retaining hormone (aldosterone) within the body (abstract). J. clin. Invest. 1955, 34, 913.

12. Davis, J. O., J. Urquhart, and J. T. Higgins, Jr. The effects of alterations of plasma sodium and potassium concentration on aldosterone secretion. J. clin. Invest. 1963, 42, 597.

13. Luetscher, J. A., Jr., and R. H. Curtis. Aldosterone: observations on the regulation of sodium and potassium balance. Ann. intern. Med. 1955, 43, 658.

14. Falbriard, A., A. F. Muller, R. Neher, and R. S. Mach. Etude des variations de l'aldostéronurie sous l'effet de surcharges en potassium et de déperditions rénales et extrarénales de sel et d'eau. Schweiz med. Wschr. 1955, 85, 1218.

15. Johnson, B. B., A. N. Lieberman, and P. J. Mulrow. Aldosterone excretion in normal subjects depleted of sodium and potassium. J. clin. Invest. 1957, $36,757$.

16. Muller, A. F., E. L. Manning, and A. M. Riondel. L'excrétion de l'aldostérone chez le sujet normal pendant la deplétion et la replétion en potassium. Helv. med. Acta 1958, 25, 547.

17. Gann, D. S., C. S. Delea, J. R. Gill, Jr., J. P. Thomas, and F. C. Bartter. Control of aldosterone secretion by change of body potassium in normal man. Amer. J. Physiol. 1964, 207, 104.

18. Lerner, B. A., and P. W. Brickner. Renal tubular acidosis and potassium loss. Amer. J. Med. 1959, 27, 664.

19. Bartter, F. C., P. Pronove, J. R. Gill, Jr., and R. C. MacCardle. Hyperplasia of the juxtaglomerular complex with hyperaldosteronism and hypokalemic alkalosis. Amer. J. Med. 1962, 33, 811.

20. Laragh, J. H., S. Ulick, V. Januszewicz, Q. B. Deming, W. G. Kelly, and S. Lieberman. Aldosterone secretion and primary and malignant hypertension. J. clin. Invest. 1960, 39, 1091.

21. Cannon, P. J., R. T. Whitlock, R. C. Morris, M. Angers, and J. H. Laragh. Effect of alphamethyl-DOPA in severe and malignant hypertension. J. Amer. med. Ass. 1962, 179, 673.

22. Laragh, J. H., J. E. Sealey, and P. D. Klein. The presence and effect of isotope fractionation in isotope dilution analysis: a factor in the measurement of aldosterone secretory rates in man in $\mathrm{Ra}$ diochemical Methods of Analysis. Vienna, International Atomic Energy Agency, 1965, p. 353.

23. Laragh, J. H., J. E. Sealey, and S. C. Sommers. Patterns of adrenal secretion and urinary excretion of aldosterone and plasma renin activity in normal and hypertensive subjects. Circulat. Res. In press.

24. Gann, D. S., J. F. Cruz, A. G. T. Casper, and F. C. Bartter. Mechanism by which potassium increases aldosterone secretion in the dog. Amer. J. Physiol. 1962, 202, 991. 
25. Moran, W. H., Jr., J. C. Rosenberg, and B. Zimmermann. The regulation of aldosterone output: significance of potassium ion. Surg. Forum 1959, 9, 120.

26. Cannon, P. J., R. P. Ames, and J. H. Laragh. The character of the aldosterone response to changes in potassium balance and to angiotensin: dependence of both effects upon sodium balance (abstract). J. clin. Invest. 1964, 43, 1294.

27. Ames, R. P., A. J. Borkowski, A. M. Sicinski, and J. H. Laragh. Prolonged infusions of angiotensin II and norepinephrine and blood pressure, electrolyte balance, and aldosterone and cortisol se- cretion in normal man and in cirrhosis with ascites. J. clin. Invest. 1965, 44, 1171.

28. Cannon, P. J., R. P. Ames, and J. H. Laragh. Unpublished observations.

30. Conn, J. W. Plasma renin activity in primary aldosteronism. Importance in differential diagnosis and in research of essential hypertension. J. Amer. med. Ass. 1964, 190, 222.

30. Denton, D. A., J. R. Goding, and R. D. Wright. Control of adrenal secretion of electrolyte active steroids. Adrenal stimulation by cross-circulation experiments in conscious sheep. Brit. med. J. 1959, 2, 522. 